\title{
ERRATA: volume 30, número 2
}

p.205 onde se lê:

\section{JOÃO A. PASCHOALIN FILHO ${ }^{1}$}

\section{Leia-se:}

\section{JOÃO A. PASCHOALIN FILHO ${ }^{1}$, DAVID DE CARVALHO ${ }^{2}$}

p.205 onde se lê:

\footnotetext{
${ }^{1}$ Prof. Dr., Universidade Nove de Julho - Engenharias, Coordenador Adjunto Engenharias, Fone: (0XX11) 3665.9028, jalexandre@uninove.br.

Recebido pelo Conselho Editorial em: 28-9-2008
}

Aprovado pelo Conselho Editorial em: 4-11-2009

Eng. Agríc., Jaboticabal, v.30, n.2, p.205-211, mar./abr. 2010

\section{Leia-se}

\footnotetext{
${ }^{1}$ Prof. Dr., Universidade Nove de Julho - Engenharias, Coordenador Adjunto Engenharias, Fone: (0XX11) 3665.9028, jalexandre@uninove.br.

${ }^{2}$ Professor Associado, FEAGRI, UNICAMP, david@ feagri.unicamp.br.

Recebido pelo Conselho Editorial em: 28-9-2008

Aprovado pelo Conselho Editorial em: 4-11-2009
}

Eng. Agríc., Jaboticabal, v.30, n.2, p.205-211, mar./abr. 2010 